\title{
Factor Analysis for Slow Budget Realization
}

\author{
${ }^{1}$ Maman Abdurrohman, ${ }^{2}$ Soffan Marsus \\ 1,2Polytechnic of STAN State Finance; Jalan Bintaro Utama Raya Sektor V, Pondok Aren, \\ South Tangerang
}

\begin{abstract}
The government of Indonesia has long experienced an uneven pattern of budget realization. Our budget realization is characterized by small absorption in the first threequarters and then piled up in the last quarter. An increase in spending at the end of the year eventually led to the quality of work on the national economy, which is not considered optimal. Through factor analysis, the researchers reviewed what factors are causing slow realization of the budget, especially for spending unit in the working area of KPPN Jakarta II. Several studies have been conducted to determine the problem, including Herriyanto (2012), BKF, LPEM-UI and IBRD (2012), Siswanto and Rahayu (2010), Miliasih (2012), Widjanarko (2013), and Fitriany (2015). Based on the factor analysis that has been conducted, it was found six factors that often slow down the realization of central government expenditure, especially for spending unit in working area of KPPN Jakarta II. The six factors include coordination, organizational culture, competence, technical constraints, administrative, and document. These six factors are derived from 27 indicators that were processed through the standard factor analysis, i.e. correlation between variables Kaiser Mayer Olkin (KMO), variables distribution and rotation of factors.
\end{abstract}

Keywords: Government Budget, Public Expenditure Management, Logic Model

\section{INTRODUCTION}

On the upcoming of the last quarter of 2015, absorption of the budget in a number of ministries were still considered as low. According to the data from Realization Report of Central Government Budget as of September 2015, budget absorption in ministries and state institutions under the Ministry of Politics, Laws and Security Coordination was 51.1 percent in average, ministries and state institutions under the Ministry of Economics Coordinator was 34.7 percent in average, ministries and state institutions under the Ministry of Human and Culture Development Coordinator was 37.6 percent in average, meanwhile for ministries and state institutions under the Ministry of Maritime Coordinator was the lowest, which was only $16 / 6$ percent in average.

A pragmatical step to catch up budget realization deadline which was only three months left by then was by accelerating budget realization in order to obtain the target. As a result, there was an accumulation of expenditures at the end of the year which eventually led to the quality of work and the generated impact on the national economy which is no longer optimal. Swaramarinda \& Andriani (2011) stated that governmental spending significantly affects economic growth. Capital and goods spending secures a strategic position in improving the speed of national economic growth. There is also a rumor that government's capital expenditure may play a role as the prime mover in economics. An accumulating budget 
realization at the end of the year turns the effect and impact generated from budget expenditure especially this goods and services spending on the national economics is not optimal. According to the data, there is a significant imbalance between absorption in the semester I and semester II in central government. This can be seen in Table 1.

Table 1: Realization of Goods and Capital Expenditure Budget in Central Government Year of 2012-2015

\begin{tabular}{|l|l|l|l|l|c|}
\hline \multirow{2}{*}{ Year } & \multirow{2}{*}{ Semester } & \multicolumn{4}{|l|}{ Type of Expenditure } \\
\cline { 3 - 6 } & & Goods (Quintillion) & $\%$ & Capital (Quintillion) & $\%$ \\
\hline 2012 & I & 41.74 & 22.2 & 30.62 & 20.15 \\
\hline & II & 140.88 & 65.84 & 145.1 & 59.31 \\
\hline 2013 & I & 44.98 & 22.41 & 34.03 & 18.46 \\
\hline & II & 169.72 & 66.3 & 180.86 & 74.5 \\
\hline 2014 & I & 57.15 & 26.52 & 25.89 & 14.06 \\
\hline & II & 176.62 & 63.96 & 147.35 & 77.58 \\
\hline 2015 & I & 50.06 & 20.96 & 26.28 & 9.53 \\
\hline
\end{tabular}

Source: Processed from Budget Realization Report (Laporan Realisasi Anggaran - "LRA") of Central Government in 2012-2015

Absorption of goods expenditure and capital expenditure budgets by working unit (satuan kerja - "satker") in the working area KPPN Jakarta 2 holds out the similar absorption realization trend. Capital and goods expenditure budget is likely to be slowly absorbed in the beginning of the year and is accelerated at the end of the year. This can be seen in figure I.1 and figure I.2.

The condition above reflects that there is a problem in the process of expenditure budget absorption, particularly for goods expenditure and capital expenditure. Some researchers had conducted research to identify such problem, among other things, are Herriyanto (2015), collaborative research of BKF, LPEM UI and IBRD (2015), Susanto \& Rahayu (2015), Miliasih (2015), (Sigit Wijanarko, (2015), and Fitriany et al. (2015). Most of these research, excluding Widjanarko (2013) focusing on examining absorption in Kemenkum HAM, as well as Fitriany, whose research focus was in Pekalongan City, used data in 2011 or 2010. The result of those research can be used as reference.

However, due to the fact that that research was conducted in the years when the condition of regulation and policy, work flow, or the facilities and infrastructures were different from the current condition, then there is a possibility that there was a condition which has not been portrayed by those research, particularly for the condition at the end of 2015. In accordance with such consideration, the author is interested in digging deeper the factors decelerating budget absorption in working unit in KPPN Jakarta 2 environment. 


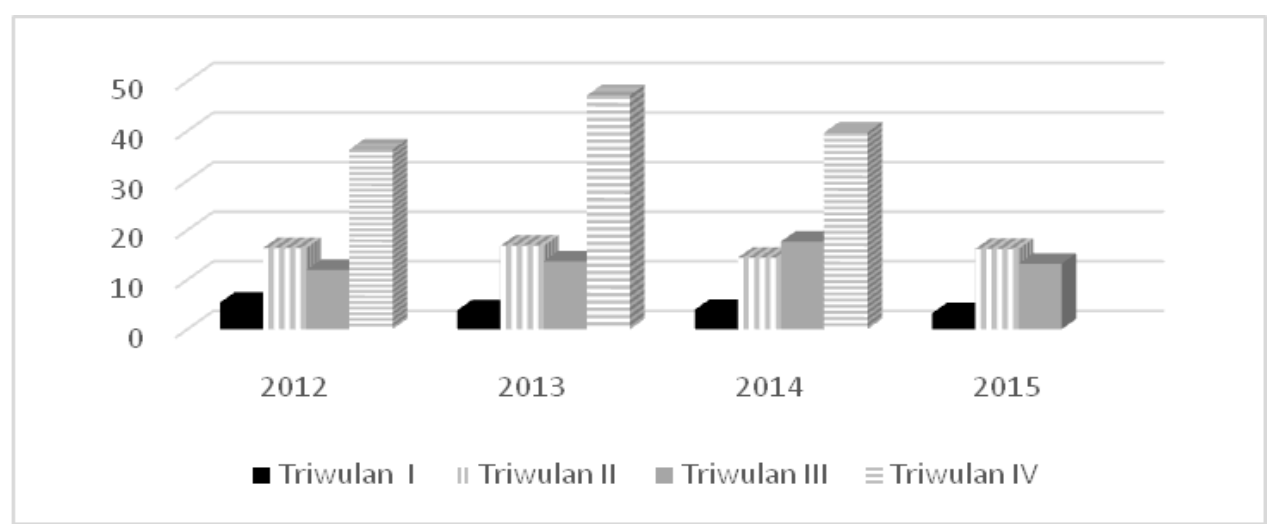

Figure 1: Diagram of Quarterly Goods Expenditure Budget Absorption Realization for Working Unit Area of KPPN Jakarta 2

Source: Processed from Authority Budget Realization Report of BUN KPPN Jakarta 2

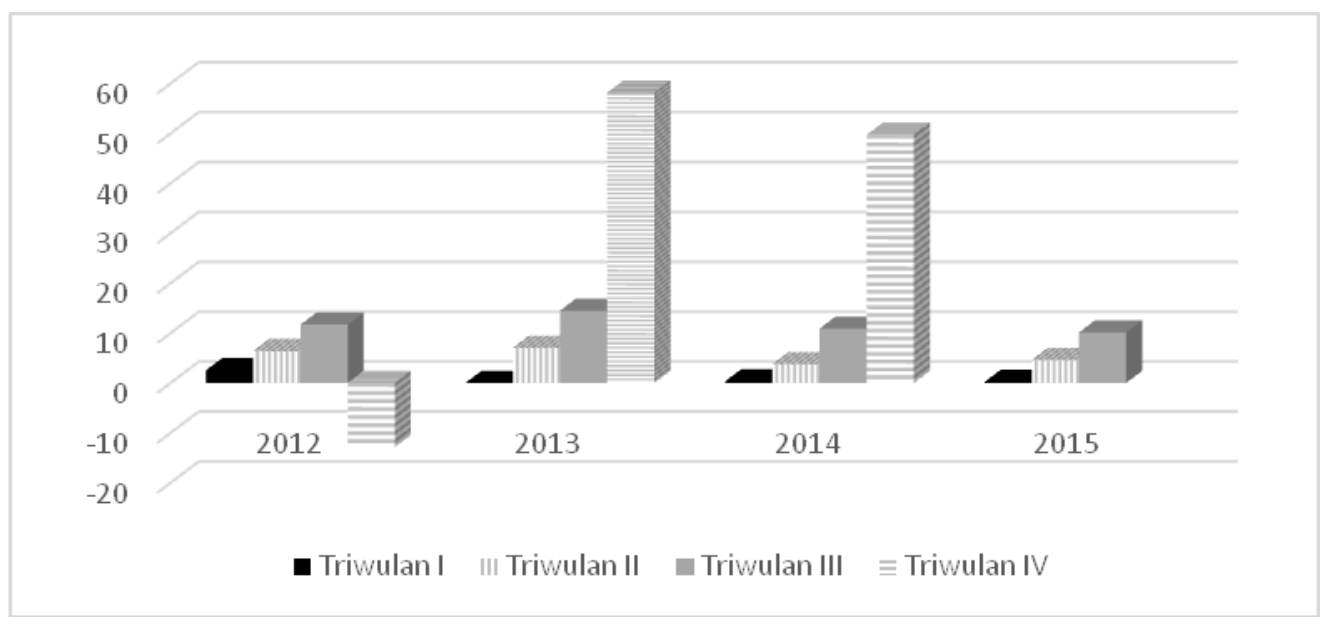

Figure 2: Diagram of Quarterly Capital Expenditure Budget Absorption Realization for Working Unit Area of KPPN Jakarta 2

Source: Processed from Authority Budget Realization Report of BUN KPPN Jakarta 2

\subsection{Research Problem(s) and Scope(s)}

Therefore, the problem of this research is to identify the factors decelerating budget absorption in working unit in payment area of KPPN Jakarta 2 particularly for goods and capital expenditure. In this research, the Author limits the scope of research to the working units in the payment area of KPPN Jakarta 2. Moreover, there is a limitation to the types of expenditure being examined, which only includes goods expenditure and capital expenditure using data from 2012-2015.

\subsection{Purpose(s) and Significance of the Research}

Along with background of the study and problems set out above, this research aims to dig deeper the factors decelerating expenditure budget in central government, particularly for goods and capital expenditures. Results of this research are expected to provide several benefits to the government as consideration and suggestion in their attempt to solve the problems regarding budget absorption. In addition, this research is also expected to provide an overview and evaluation related to budget realization occurring in the field, especially KPPN Jakarta 2 environment. 


\subsection{Result(s) of Previous Research}

Several previous research related to the factors of the delay in budget absorption, among other things, are:

1. Herriyanto (2012) conducted research on the factors affecting expenditure budget absorption from the working unit in Jakarta payment area using exploratory factor analysis (EFA) method. The result of the research found that capital and goods expenditure absorption accumulated in the IV quarter of more than $50 \%$. Delay in expenditure budget absorption in working unit in Jakarta is caused by (1) planning factor (2) administrative factor (3) human resources factor (4) procurement documents factor and (5) inventory reimbursement factor.

2. A collaboration research conducted by BKF, LPEM-UI and World Bank staffs (2012) conducting an exploratory study of DIPA in order to identify the obstruction in implementing the budget in infrastructural sector using 36 DIPA sampling method related to the infrastructure, identified that the problem in budget implementation occurs at the step of arranging the budget and procurement. Regarding blocking factor, it is found that from 36 DIPA as samples, there are 16 DIPA blocked, and the ones related to revision said that $90 \%$ of working units stating that they implement DIPA revision and more than $60 \%$ revised it for more than 3 times.

3. Research conducted by Siswanto and Rahayu (2010) on the low absorption of spending in seven biggest ministries/institutes managing the spending, namely Ministry of Defense, Ministry of National Education, Ministry of Public Works, Police, Ministry of Health, Ministry of Transportation and Ministry of Finance. The result of the research shows that there are 4 main factors causing the low budget absorption, namely: (1) K/L internal (2) goods and services procurement mechanism (3) revision mechanism and budget implementation documents and (4) other issues. Such research also identified that the area experiencing a delay in absorption majority is in the Western area of Indonesia.

4. Research conducted by Miliasih (2011) regarding the delay in spending budget absorption of working unit in State Ministry/Institution Year of 2010 in KPPN Pekanbaru payment area. From the result of the research, the main causes of delay are found which is in the issue regarding working unit internal, namely: (1) problem related to budget realization process, (2) problem related to technical policy, and (3) cultural problem of budget manager in working unit.

5. Research conducted by Wijanarko (2013) regarding the factors affecting budget absorption in Ministry of Law and Human Rights found that the main factors which may disrupt budget absorption are (1) revision factor (2) source of fund factor and (3) types of working units' factor.

6. A research conducted by Fitriany, Masdjojo, and Suwarti (2015) regarding factors causing budget accumulation trend at the end of the year stated that from the selected independent variables, namely (1) Budget Planning (2) Budget Implementation (3) Working Unit Internal (4) Human Resources (5) Documents, and (6) Administration, there are only found two variables which significantly affects this spending accumulation. Namely (1) human resources factor and (2) document factor.

From the research set out above, then, from each main cause factors, there are problematic variables forming such factors. This will be defined in Table 2. 
Maman Abdurrohman, Soffan Marsus

Factor Analysis for Slow Budget Realization

Table 2: Variables/Indicators of Problems regarding Factors Decelerating Budget Absorption in Previous Research

\begin{tabular}{|c|c|c|c|c|c|c|}
\hline \multirow{2}{*}{$\begin{array}{c}\text { Decelerating } \\
\text { Factors }\end{array}$} & \multicolumn{4}{|c|}{ Research } & & \\
\hline & Herriyanto & $\mathrm{BKF}$ & Susanto & Miliasih & Wijanarko & Fitriany \\
\hline \multirow{2}{*}{$\begin{array}{l}\text { Decelerating } \\
\text { Factors }\end{array}$} & \multicolumn{6}{|c|}{ Research } \\
\hline & Herriyanto & $\begin{array}{l}\text { BKF } \\
\text { Team }\end{array}$ & Susanto & Miliasih & Wijanarko & Fitriany \\
\hline Planning & $\mathrm{V}$ & & & & & \\
\hline Human Resources & $\mathrm{V}$ & & & $\mathrm{v}$ & & $\mathrm{v}$ \\
\hline DIPA & $\mathrm{V}$ & $\mathrm{v}$ & $\mathrm{v}$ & & & $\mathrm{V}$ \\
\hline $\begin{array}{c}\text { Stock } \\
\text { Reimbursement }\end{array}$ & $\mathrm{V}$ & & & & & \\
\hline $\begin{array}{c}\text { Procurement of } \\
\text { Goods and } \\
\text { Services }\end{array}$ & & $\mathrm{v}$ & $\mathrm{v}$ & v & & \\
\hline K/L Internal & & & $\mathrm{v}$ & & & \\
\hline Budget Revision & & $\mathrm{v}$ & $\mathrm{v}$ & & $\mathrm{v}$ & \\
\hline Technical Policy & & & & v & & \\
\hline Source of Fund & & & & & $\mathrm{v}$ & \\
\hline $\begin{array}{c}\text { Type of Working } \\
\text { Unit (Satker) }\end{array}$ & & & & & $\mathrm{v}$ & \\
\hline
\end{tabular}

Source: Processed from Data from Previous Research

\section{RESEARCH METHOD}

\subsection{Research Framework}

This research related to the concept of governmental spending, state financial, state treasury, budget, implementation of the budget in Indonesia, organizational culture and competence. The overall concepts underlie the framework of problem-solving in this research. The framework of this research acts as a summary or collaboration from those concepts upon budget realization which is shown in Figure 3.

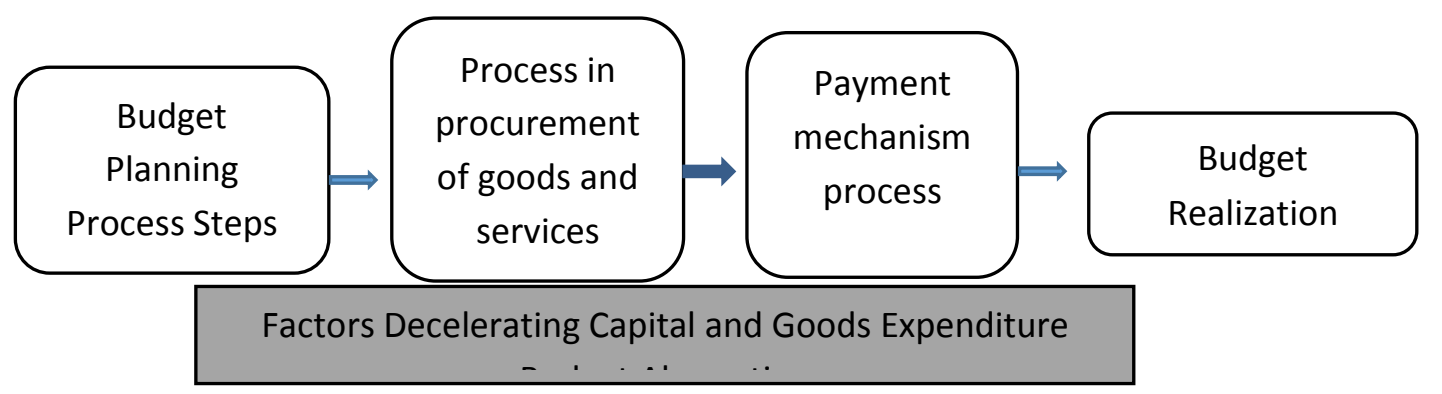

Figure 3: Problem Solving Framework

Problem-solving flow in this research was started by conducting an evaluation of the report of budget realization of working unit in KPPN Jakarta 2 payment area. Next, according to the result of report evaluation, an analysis of budget realization or budget absorption delay rate particularly for capital and goods expenditure in state ministry/institution is conducted. From the analysis, the next step is by analyzing the factors causing a delay in budget absorption. This is conducted by exploring variables causing delay in budget absorption, then asking for assessment and perception of respondents upon those exploration result variables through 
questionnaire sheet in order to find out the problems causing disruption on working unit spending budget absorption particularly for capital and goods spending.

\subsection{Research Objects Selection}

This research will evaluate budget realization in working unit in KPPN Jakarta 2 working area, followed by analyzing working unit spending budget realization process steps in order to find out the problems causing disruption on working unit spending budget absorption at the early quarters and accumulation of budget absorption in the last quarter. KPPN Jakarta 2 is a vertical instance under Directorate General of Treasury. The reason for selecting KPPN Jakarta 2 as an object of the study and the focus selection on the capital and goods expenditure, among other things, are:

1. This selection of KPPN Jakarta 2 object is conducted under consideration that it supervises 273 working units with the total number of managed ceiling is Rp1,025.5 or $50.28 \%$ from the total ceiling of National APBN spending as many as Rp2,039.5 quintillion.

2. The complexity of spending types and the variety of working unit types from KPPN Jakarta 2 will be considered as sufficiently representing as a research sample.

3. Focus selection on capital and goods spending is conducted under consideration as described by Swaramarinda and Indriani $(2013,3)$ that capital and goods spending has a strategic position in increasing the speed of national economic growth. There is also a rumor that government's capital expenditure may play a role as the prime mover in economics.

4. Research data availability. Sarwono (2014) described that sample size should be at least 100 with error tolerance $10 \%$. Ideally, sample size should be around 400 with $5 \%$ tolerance. The number of working units at State Ministry/Institute in KPPN Jakarta 2 payment area has met the requirements to conduct research using factor analysis method, which is 273 working units.

\subsection{Data Collection}

This research utilizes primary data and secondary data. Secondary data used in this research are data from books, magazines, journals and reports. For example, documents related to this research includes budget realization report for working unit in KPPN Jakarta 2 payment area year 2012 until 2015 per quarter, and other literature related to the research. Meanwhile, primary data used in this research are obtained from questionnaire distribution process. The structure of questionnaire used in this research consists of opened and closed questions. Closed questions come up in the form of the list of questions given or distributed to the respondents for them to fill out according to each perception of respondents' form working unit using Likert scale. In opened questions, the respondents shall answer the questions in blank fields in the event that there is the issue not stated in the closed questions. The population of this research is all working units in KPPN Jakarta 2 payment scope. According to the data obtained from KPPN Jakarta 2, the total number reached 273 working units in 2015. Parts of overall working units will be selected as samples or respondents to be provided with research questionnaire.

This research utilizes exploratory factor analysis. Sampling or respondent determination is conducted using the convenience sampling (accidental sampling) method. According to Sekaran (2003), using convenience sampling, the sample is selected based on the ease to get. This is pursuant to the statement pointed by Sugiyono in Abubakar (2015) that anybody considered eligible as data source will be provided with the questionnaire.

However, different from the previous studies, the respondents selected are only working unit financial manager of whom in the DIPA, the relevant manages capital and goods expenditure. 
This is conducted so that there is no bias on the result of the research. By specifying on the respondents who manage capital and goods spending, the result of the research will be free from effect bias of spending other than both types.

\subsection{Research Variables}

Variables searching is conducted by data and information collection about budget absorption according to literature research, namely finding problematic factors from the previous studies, seminary results related to the problems in delay of spending budget absorption, evaluation report of budget implementation and conducting an in-depth interview to the staffs in Directorate of Budget Implementation and several treasurers in KPPN working units. Moreover, these collected factors become materials for arranging interview and questionnaire questions to the interviewees.

From this early exploration step, as many as a hundred and eleven variables of problems as set out in the attachment are obtained. On the other hand, from the result of combining variables of problems from the previous studies, fourteen variables of problems are updated and added to this initial questionnaire. These new fourteen variables is a result of adjustment of circumstances change in the State financial management, and the findings on variables of new problems as a result of kinds of literature exploration, field observation or an in-depth interview with the experts. The fourteen problems variables/indicators, among other things, are:

1. A bad SPAN contract data processing.

2. Contractor preference to bill at the end of the year and the slow process in working unit.

3. A new system in the disbursement of funds (SPAN, Cash Planning).

4. Not-integrated working mechanism at particular units (position handover is not accompanied with documents/files handover).

5. A huge number of complaints by Non-governmental organization (NGO) to Police of RI and Attorney upon budget realization in working unit.

6. Activities of local election in several areas funded from APBD which causes local election budget for Police APBN delayed.

7. Concurrent local election activities held in December.

8. Combination/addition of institutional ministry.

9. Nomenclature change in institutional ministry.

10. The officials are not eligible in translating the policy (less risk taking), does not have the guts in taking tender due to saving the policy.

11. Social assistance fund, the name of receiver or supplier is not properly inputted.

12. The new DK/TP DIPA is published in II, III and IV-quarters.

13. New working units which gets their very first time in receiving DK/TP DIPA so that they shall learn about disbursement of fund mechanism from the very start.

14. Insufficient socialization in procedure of goods/services procurement (previously insufficient socialization of President Regulation No. 54 Year 2010).

Moreover, these 111 variables are taken as question items in the questionnaires to the practitioners in monitoring and evaluation fields, namely employees in Directorate of Budget Implementation in Directorate General of Treasury of Ministry of Finance, or practitioners in the field of financial management, particularly in KPPN offices.

This questionnaire uses rank/score using ratio scale 1 up to 9 . Scale of 1 up to 9 is considered sufficiently representing human perception (Permadi, 1992). Those scales reflect the truth level of a variable. The bigger the number chosen, the higher truth level of a variable is. Meaning/value of those variable scales are:

1: not really true

3: a bit true 
5: true

7: very true

9: truly true

$2,4,6,8$ is median value of the values above.

Those questionnaire results will generate ranks from research variables. From a hundred and eleven variables which will be taken as materials of questionnaire to the working units. 30 variables with the top rank will be selected. Selection of these 30 variables is based on a consideration that the respondents can concentrate on filling out the questionnaires with a reasonable number of questions.

\subsection{Data/Factor Analysis Method}

Result of questionnaire and interview on interviewees, later on, is analyzed using exploratory factor analysis data processing method using IBM SPSS Statistics 22. Amir (2015) explained exploratory factor analysis aims to explore a field to find main construct or dimension. Factor analysis enables the Author to analyze what becomes an underlying factor or something underlying a factor. Factor analysis also explains how strong an item is affected by the certain factor.

Ghozali (2013) added, factor analysis eagers to identify a way, to sum up, information existed in the original (initial) variable into one set of new dimension or variate (factor). In order to create a questionnaire, according to Amir (2015), factor analysis can be used to shorten the questionnaire by removing items which are statistically, the loading factor is not quite strong upon a particular factor.

\subsection{Factor Analysis Definition}

Factor analysis is a statistical tool used to reduce variables from a set of variables. Variables reduction is conducted by constructing inter-correlation (correlation) to a set of the data variable. Inter-correlation among these variables then defined as factor. From reduction result factor, there will be found a pattern and association of a set of defined variables.

\subsection{Factor Analysis Purpose}

There are various purposes of factor analysis. Among other things is to identify the association among variables (data structure identification) by conducting correlation test, of which in this event, it involves two things, namely: R Factor Analysis, if the correlation is conducted among variables (column); and $\mathrm{Q}$ Factor Analysis, if correlation is conducted among respondents (row). Other purposes of factor analysis are to reduce data, create a new set of variables (referred to as factor) to replace several particular variables. In this event, what needs to be noted are factor and contribution of variables to the factors; factor loading; and factor score.

\subsection{Assumption in Factor Analysis}

Assumptions used in analyzing factor, among other things are the requirements for multicollinearity, which means correlation among independent variables which should be strong, e.g., more than 0.5, partial correlation (correlation between 2 variables by still considering other variables) occurring should stay small. In SPSS application, partial correlation is shown in Anti-Image Correlation; all correlation matrix testing (correlation among variables) measured using Bartlett Test of Sphericity unit or Measure of Sampling Adequacy (MSA); and in several cases, Normality assumption from variables or factors occurring shall be met.

\subsection{Steps in Factor Analysis Factor}

According to Pramesti $(2015,167)$, steps in factor analysis is as follows: 
1.Conducting validity and reliability test on the instruments.

Ghozali $(2011,52)$ explains that the validity test is used to measure the validity of a questionnaire. Validity test is conducted by comparing $r$ counted value with $r$ table for the degree of freedom $(\mathrm{df})=\mathrm{n}-2$, in this case, $\mathrm{n}$ is the number of samples. An instrument is considered as valid if the $r$ counted $>r$ table. Regarding reliability test, Ghozali $(2011,47)$ described that the actual reliability is a tool to measure a questionnaire which is an indicator of a variable or construct. A questionnaire is considered reliable if the answer of a person to the question is constant or stable from time to time. A construct or variable is considered as reliable if it shows a value of Cronbach's Alpha> 0,70 (Nunnally, 1994 inGhozali, 2011).

1. Conducting inter-variables correlation test.

Factor analysis process is based on correlation matrix between one variable and other variables, to obtain factor analysis of which all variables should be correlated. In order to test the accuracy of factor model, a statistical test used is barletts test sphericity and KiserMayer-Olkin (KMO) to identify the sufficiency of samples, where:

a. KMO Value of 0.9 is excellent

b. KMO Value of 0.8 is good

c. KMO Value of 0.7 is medium, rather good

d. KMO Value of 0.6 is okay

e. KMO Value of 0.5 is worse

f. KMO Value of 0.5 is rejected

2. Determination of a total number of factors.

Factors determination is intended to represent the analyzed variables based on the value of eigenvalue and the total percentage of the variants. Only the factors with the same eigenvalue or more than one retained in the factor analysis model, meanwhile the other not eligible will be removed from the model.

3. Variables distribution into factors.

In this step, the variables will be inputted into factors according to SPSS application calculation. Herriyanto $(2012,45-46)$ stated that SPSS application would show component matrix according to factor loading. Factor loading shows the closeness of variables to the formed factors. The higher the factor loading, the more eligible the variable to be included in the factors. Amir (2015, 133-134) explained that the experts, referring to Field, recommended factor loading 0.72 for sample size of 50 to be considered as significant. However, several experts said that factor loading more than 0.4 could be considered appropriate.

\subsection{Factor Rotation}

The result of factor extraction in the factor matrix identifies the association between factors and individual factors, but in those factors, there are many variables correlated so that it is hard to interpret. Through matrix factor rotation, the matrix factor is transformed into the simpler matrix so that it will be easier to interpret. Factor rotation uses varimax procedure.

\subsection{Formed Factors Naming}

After reducing the indicators into several factors with factor rotation, Widarjono $(2015,205)$ explained, then, each formed factors shall be named or identified or tagged. This naming is adjusted to the characteristic of each indicator forming such factor.

\subsection{Data Processing Facility}

In order to process this data, the author utilizes computer program facilities. The computer program used to process statistical data in this research are Microsoft Excel 2013, an 
internet-based questionnaire software Google form and statistical data processor SPSS version 22.

\section{FINDINGS AND DISCUSSION}

\subsection{Research Variables Determination}

This research variables determination is conducted by distributing the questionnaire to the respondents consisting of the practitioners in monitoring and evaluation fields, namely employees in Directorate of Budget Implementation in Directorate General of Treasury of Ministry of Finance, or practitioners in the field of financial management particularly in KPPN offices. The total of selected practitioners as respondents are seven persons. From the seven practitioners, four persons are organizers in Directorate of Budget Implementation and the three others are the organizers in several separated KPPN. From a hundred and eleven questionnaires provided to these practitioners, thirty questions with the highest score are selected to be turned as questionnaire materials to the working unit in KPPN Jakarta 2 payment area. Result of this questionnaire data ranking can be seen in Table 3.

\subsection{Data Collection}

Data collection is conducted by distributing the questionnaire to the working unit in KPPN Jakarta 2 payment area. This questionnaire distribution is conducted in KPPN Jakarta 2 starting from 18 until 22 of January 2016. This distributed questionnaire comprises of three sections. Section A contains the identity of working unit; section B consists of 30 closed questions answered based on respondent's perception, section $C$ consists of opened questions regarding the steps taken by the working unit in overcoming the delay of budget absorption.

Table 3: Research Variables/Indicators Ranking Result

\begin{tabular}{|l|l|l|}
\hline No & Research Indicator(s) & Score \\
\hline 1 & $\begin{array}{l}\text { There is a culture of postponing the work in working unit, indiscipline, } \\
\text { etc }\end{array}$ & 54 \\
\hline 2 & DIPA needs to be revised since it does not meet the necessity. & 52 \\
\hline 3 & $\begin{array}{l}\text { There is no reward \& punishment mechanism in working unit budget } \\
\text { management. }\end{array}$ & 52 \\
\hline 4 & The limitation of certified goods/services procurement officials. & 50 \\
\hline 5 & $\begin{array}{l}\text { A fear and circumspection in implementing goods/service procurement } \\
\text { due to complaints and news on officials arrest and allegation of }\end{array}$ & 48 \\
\hline 6 & $\begin{array}{l}\text { Reluctance to act as procurement officials due to imbalance between } \\
\text { risk of job and the reward received. }\end{array}$ & 48 \\
\hline 7 & Multitasking in Procurement Committee title. & 47 \\
\hline 8 & $\begin{array}{l}\text { The problems related to the consultant such as consultant who has not } \\
\text { been assigned, the assigned consultant is resigned, unavailability of } \\
\text { consultant qualification and required experts. }\end{array}$ & 47 \\
\hline 9 & Lack of goods/service procurement procedure socialization & 47 \\
\hline 10 & Activity planning which is not aligned with the requirements. & 46 \\
\hline 11 & There is contract addendum. & 46 \\
\hline 12 & Incompetent goods/services provider. & 46 \\
\hline 13 & $\begin{array}{l}\text { The implementation of activity/project is not subject to the } \\
\text { plan/schedule set out in page 3 DIPA or Expenditure Budget Plan }\end{array}$ & 46 \\
\hline 14 & Delay in the budget revision process. & 45 \\
\hline
\end{tabular}




\begin{tabular}{|l|l|l|}
15 & $\begin{array}{l}\text { Activity implementation that needs to wait for instruction from K/L } \\
\text { central office. }\end{array}$ & 44 \\
\hline 16 & Activity budget is blocked/marked since there is no supporting data. & 43 \\
\hline 17 & $\begin{array}{l}\text { Limited activities, such as vehicles procurement and building } \\
\text { development. }\end{array}$ & 42 \\
\hline 18 & $\begin{array}{l}\text { The centered-implementation materials/goods procurement which is } \\
\text { received late. }\end{array}$ & 41 \\
\hline 19 & Lack of understanding regarding regulations on payment mechanism. & 41 \\
\hline 20 & SPM errors due to ineligibility. & 41 \\
\hline 21 & Incompetent procurement human resources. & 40 \\
\hline 22 & $\begin{array}{l}\text { Disharmony in the regulation regarding planning, implementation, and } \\
\text { disbursement of funds. }\end{array}$ & 40 \\
\hline 23 & $\begin{array}{l}\text { A mistake in account determination, so that budget documents need to } \\
\text { be revised. }\end{array}$ & 39 \\
\hline 24 & $\begin{array}{l}\text { Decree of Appointment/Replacement of KPA, PPK, PP-SPM Treasury } \\
\text { Officials and Spending Treasurer is late to be specified. }\end{array}$ & 39 \\
\hline 25 & Officials/employees of financial management are mutated frequently. & 39 \\
\hline 26 & Goods unit price in cost standard (SBU/SBK) is too low/high. & 38 \\
\hline 27 & A lateness in arranging in auction implementation schedule. & 38 \\
\hline 28 & $\begin{array}{l}\text { A difficulty in performing coordination between central unit and the } \\
\text { regional unit in executing activities/projects. }\end{array}$ & 38 \\
\hline 29 & $\begin{array}{l}\text { Budget Plan (Rencana Anggaran Biaya - "RAB") does not match to the } \\
\text { cost unit. }\end{array}$ & 37 \\
\hline 30 & Specification of goods.materials is unavailable/hard to obtain. & 37 \\
\hline & & \\
\hline
\end{tabular}

Source: Processed from questionnaire result, 2016

From 140 exemplars, the total returned questionnaires are $113(80.7 \%)$. These returning questionnaire then examined for the completeness of answer as can be seen in table IV.2. Next, the data that will be processed using exploratory factor analysis is data from B section questionnaire. As set out in table IV.1, this B section is filled out as many as 104 exemplars. This number is considered appropriate to be used later on as materials of factor analysis based on Slovin formula, i.e., more than 74 respondents. Therefore, the questionnaire that can be used for advance analysis are those 104 exemplars.

Table 4: Questionnaire Answers Completeness Examination Result

\begin{tabular}{|c|c|c|}
\hline Description & $\begin{array}{c}\text { Total Number of } \\
\text { Questionnaires }\end{array}$ & Explanation \\
\hline Distribution & 140 & $80.7 \%$ returned \\
\hline Returned & 113 & 105 completely filled out \\
\hline First Part (Letter A) & 113 & 104 completely filled out \\
\hline Second Part (Letter B) & 113 & \\
\hline
\end{tabular}

Source: Processed from questionnaire result, 2016

\subsection{Validity test}

A questionnaire is considered as valid if the questions in the questionnaire are able to reveal something measured using the questionnaire. Statistically, questionnaire question items are considered as valid if $r$ counted $>r$ table. This $r$ counted is obtained from data processing using SPSS 22.0 application. There are 30 items of which validity shall be tested. By validation process using SPSS 22.0 with 95\% significance level $(a=5 \%)$, there are 3 invalid question items, namely Q2, Q11, and Q17. Meanwhile, the 27 valid question items can be 
analyzed later on since they have $r$ counted bigger than $r$ table value ( $r$ counted $>0.195$; $\mathrm{n}=104$ ). Validity test result can be seen in Table 5.

Table 5: Questionnaire Validity Test Result

\begin{tabular}{|l|l|l|l|}
\hline Question & r-counted & R table & Description \\
\hline Q1 & 0.446 & 0.195 & Valid \\
\hline Q2 & 0.146 & 0.195 & Invalid \\
\hline Q3 & 0.314 & 0.195 & Valid \\
\hline Q4 & 0.489 & 0.195 & Valid \\
\hline Q5 & 0.413 & 0.195 & Valid \\
\hline Q6 & 0.420 & 0.195 & Valid \\
\hline Q7 & 0.504 & 0.195 & Valid \\
\hline Q8 & 0.385 & 0.195 & Valid \\
\hline Q9 & 0.255 & 0.195 & Valid \\
\hline Q10 & 0.591 & 0.195 & Valid \\
\hline Q11 & -0.03 & 0.195 & Invalid \\
\hline Q12 & 0.495 & 0.195 & Valid \\
\hline Q13 & 0.491 & 0.195 & Valid \\
\hline Q14 & 0.299 & 0.195 & Valid \\
\hline Q15 & 0.489 & 0.195 & Valid \\
\hline Q16 & 0.478 & 0.195 & Valid \\
\hline Q17 & 0.048 & 0.195 & Invalid \\
\hline Q18 & 0.484 & 0.195 & Valid \\
\hline Q19 & 0.594 & 0.195 & Valid \\
\hline Q20 & 0.258 & 0.195 & Valid \\
\hline Q21 & 0.512 & 0.195 & Valid \\
\hline Q22 & 0.564 & 0.195 & Valid \\
\hline Q23 & 0.557 & 0.195 & Valid \\
\hline Q24 & 0.515 & 0.195 & Valid \\
\hline Q25 & 0.531 & 0.195 & Valid \\
\hline Q26 & 0.403 & 0.195 & Valid \\
\hline Q27 & 0.590 & 0.195 & Valid \\
\hline Q28 & 0.551 & 0.195 & Valid \\
\hline Q29 & 0.473 & 0.195 & Valid \\
\hline Q30 & 0.475 & 0.195 & Valid \\
\hline & & & \\
\hline
\end{tabular}

Source: Processed from questionnaire data, 2016

\subsection{Reliability test}

After the 27 question items passed validity test, the next step is reliability test. According to Augustine and Kristaung $(2013,73)$, an instrument is considered as reliable if the coefficient value of reliability measured is bigger than 0.60 . The result of test using SPSS shows Cronbach `s Alpha score from 27 question items of the questionnaire is 0.896 , or bigger than 0.60 . Therefore, the questionnaire is considered as reliable and the existing data can be analyzed later on using exploratory factor analysis. Reliability test result can be seen in Table 6.

Table 6: Questionnaire Reliability Test Result

\begin{tabular}{|l|l|l|}
\hline Cronbach's Alpha & Cronbach's Alpha Based on Standardized Items & N of Items \\
\hline .896 & .899 & 27 \\
\hline
\end{tabular}

Source: Processed from questionnaire data, 2016 


\section{Factor Analysis}

\subsection{Inter-variables Correlation Test.}

The next step is by testing the inter-variables correlation in the questionnaire. This test is required for identifying eligibility of factor analysis to be done.

These inter-variables correlation test is done through Kaiser Mayer Olkin (KMO) testing, Measure of Sampling Adequacy and Bartlett Test of Sphericity. From testing result on 27 question items, there is generated value of KMO Measure of Sampling Adequacy as many as .787 (>0.5) and Bartlett Test of Sphericity as many as $0.000(<0.05)$, so that it is eligible for the advanced factor analysis to be conducted (Table 7).

Table 7: Inter-variables Correlation Test Result using Kaiser Mayer Olkin (KMO) testing, Measure of Sampling Adequacy and Bartlett Test of Sphericity

\begin{tabular}{|l|l|l|}
\hline \multicolumn{2}{|l|}{ Kaiser-Meyer-Olkin Measure of Sampling Adequacy. } & .787 \\
\hline \multirow{3}{*}{ Bartlett's Test of Sphericity } & Approx. Chi-Square & 1325.255 \\
\cline { 2 - 3 } & Df & 351 \\
\cline { 2 - 3 } & Sig. & .000 \\
\hline
\end{tabular}

Source: Processed from questionnaire data, 2016

Another test result is shown by MSA value on Anti-Image Correlation also exhibits that all question items have MSA value bigger than 0.5. According to those results, the advanced factor analysis can be done.

\subsection{Determination of total number of factors}

The next step is to determine the total number of factors formed using an approach based on eigenvalue score (total number of variant describable by each factor). According to extraction result, there are 6 optimal factors with eigenvalue score bigger than 1 and variance percentage of 62.5 , of which the details are as follow:

a. The first factor has an eigenvalue of 7.787 which can describe the variation of all items as many as 28.839 .

b. The second factor has eigenvalue of 2.867 which is able to describe the variation of all items as many as $10.617 \%$.

c. The third factor has eigenvalue of 2.169 which is able to describe the variation of all items as many as $8.035 \%$.

d. The fourth factor has eigenvalue of 1.616 which is able to describe the variation of all items as many as $5.985 \%$.

e. The fifth factor has eigenvalue of 1.317 which is able to describe the variation of all items as many as $4.878 \%$.

f. The sixth factor has eigenvalue of 1.119 which is able to describe the variation of all items as many as $4.145 \%$.

It shows that of 27 indicators is turned into one factor, then such factor is able to describe indicator variation as many as $28.839 \%$. Should it be turned into two factors, then both factors are able to describe indicator variation as many as $39.457 \%$. With $28.839 \%$ of variation are from the first factor and from the second factor is $10.617 \%$. Moreover, if these 27 factors is divided into six factors, then the six factors formed will be able to describe indicator variation as many as $62.5 \%$. It means that, the 27 -existing factor will be able to describe $62.5 \%$ of overall indicator variations. Meanwhile, as for the remaining, they will be described using other factors apart of those six factors. 
Maman Abdurrohman, Soffan Marsus

Factor Analysis for Slow Budget Realization

\subsection{Distributing variables into factors}

Table 8: Component Matrix

\begin{tabular}{|c|c|c|c|c|c|c|}
\hline & \multicolumn{6}{|c|}{ Component } \\
\hline & 1 & 2 & 3 & 4 & 5 & 6 \\
\hline Q10 & .697 & & & & & \\
\hline Q28 & .693 & & & & & \\
\hline Q22 & .682 & & & & & \\
\hline Q27 & .649 & & & & & \\
\hline Q19 & .629 & & & & & \\
\hline Q23 & .604 & & & & & \\
\hline Q30 & .602 & & & & & \\
\hline Q13 & .601 & & & & & \\
\hline Q16 & .600 & & & & & \\
\hline Q29 & .591 & & & & & \\
\hline Q15 & .580 & & & & & \\
\hline Q18 & .577 & & & & & \\
\hline Q24 & .559 & & & .421 & & \\
\hline Q25 & .558 & .426 & & & & \\
\hline Q21 & .537 & & & & & \\
\hline Q12 & .531 & & & .410 & & \\
\hline Q26 & .505 & & .494 & & & \\
\hline Q4 & .504 & .436 & & & & \\
\hline Q1 & .485 & & -.467 & & & \\
\hline Q6 & & .644 & & & & \\
\hline Q5 & & .643 & & & & \\
\hline Q7 & .498 & .509 & & & & \\
\hline Q3 & & .475 & & & & \\
\hline Q20 & & & .649 & & & \\
\hline Q8 & .449 & & .632 & & & \\
\hline Q9 & & & .432 & & .512 & \\
\hline Q14 & & & & .404 & & .411 \\
\hline
\end{tabular}

Source: data of questionnaire result, processed using SPSS 22

After the total number of factors are generated, the next step is to distribute the 27 question items into such 6 factors formed according to their loading factor using component matrix (Table IV.7). According to table I, it can be seen that the majority of question items are divided into the factors in such imbalance manner. Therefore, a factor rotation is required so that all existing variables may fill the six factors formed optimally. 
Maman Abdurrohman, Soffan Marsus

Factor Analysis for Slow Budget Realization

\subsection{Factor rotation}

Table 9: Rotated Component Matrix

\begin{tabular}{|c|c|c|c|c|c|c|}
\hline & \multicolumn{6}{|c|}{ Component } \\
\hline & 1 & 2 & 3 & 4 & 5 & 6 \\
\hline Q29 & .788 & & & & & \\
\hline Q28 & .781 & & & & & \\
\hline Q30 & .728 & & & & & \\
\hline Q16 & .666 & & & & & \\
\hline Q18 & .655 & & & & & \\
\hline Q6 & & .799 & & & & \\
\hline Q5 & & .768 & & & & \\
\hline Q7 & & .690 & & & & \\
\hline Q25 & & .641 & & & & \\
\hline Q3 & & .592 & & & & \\
\hline Q4 & & .575 & & & & \\
\hline Q23 & .434 & .439 & & & & \\
\hline Q27 & .410 & .419 & & & & \\
\hline Q12 & & & .694 & & & \\
\hline Q22 & .489 & & .633 & & & \\
\hline Q1 & & .416 & .630 & & & \\
\hline Q13 & & & .627 & & & \\
\hline Q10 & .463 & & .610 & & & \\
\hline Q19 & & .405 & .451 & & & \\
\hline Q9 & & & & .833 & & \\
\hline Q8 & & & & .772 & & \\
\hline Q26 & .418 & & & .515 & & .423 \\
\hline Q15 & & & & .487 & & \\
\hline Q21 & & & & & .673 & \\
\hline Q20 & & & & & .517 & \\
\hline Q14 & & & & & & .831 \\
\hline Q24 & & & & & & .585 \\
\hline
\end{tabular}

Source: Data of questionnaire result, processed using SPSS 22

This Factor Rotation is needed to generate the factors not correlated with each other. Such factor rotation is done using SPSS and resulting in Rotated Component Matrix (Table IV.8). By this rotation, 24 existed variables can be optimally distributed into six formed factors. The first factor consists of five variables, they are Q16, Q18, Q28, Q29, and Q30. The second factor consists of eight variables, they are Q3, Q4, Q5, Q6, Q7, Q23, Q25, and Q27. The third factor consists of six variables, they are Q1, Q10, Q12, Q13, Q19, and Q22. The fourth factor consists of four variables, they are Q8, Q9, Q15, and Q26. The fifth factor consists of two variables, they are Q20 and Q21. And the last one, the sixth factor consists of two variables, they are Q14 and Q24.

\subsection{Formed factors naming}

After conducting factor rotation and all variables are distributed into six factors optimally, the next step is naming those formed factors. This naming is conducted based on the characteristics generally representing the variables forming those factors. Those factors can be described as follow:

a. The first factor (eigenvalues 7.787) is called coordination factors. Variables forming this coordination factor can be described in details as follow: 
1) Variable (Q16) Activity budget is blocked/marked since there is no supporting data (factor loading 0.666).

2) Variable (Q18) The centered-implementation materials/goods procurement which is received late. (factor loading 0.655 ).

3) Variable (Q28) A difficulty in performing coordination between central unit and the regional unit (factor loading 0.781).

4) Variable (Q29) Budget Plan (Rencana Anggaran Biaya - "RAB") does not match to the cost unit (factor loading 0.788).

5) Variable (Q30) Specification of goods. materials is unavailable/hard to obtain. (factor loading 0.728 ).

b. Second factor (eigenvalues 2.867) is called organizational culture factors. Variables forming this organizational culture factors are as follow:

1) Variable (Q3) There is no reward \& punishment mechanism in working unit budget management (factor loading 0.592).

2) Variable (Q4) The limitation of certified goods/services procurement officials (factor loading 0.575).

3) Variable (Q5) A fear and circumspection in implementing goods/service procurement (factor loading 0.768).

4) Variable (Q6) Reluctance to act as procurement officials due to the imbalance between risk of job and the reward received (factor loading 0.799).

5) Variable (Q7) Multitasking in Procurement Committee title. (factor loading 0.690).

6) Variable (Q23) A mistake in account determination, so that budget documents need to be revised (factor loading 0.439 ).

7) Variable (Q25) Officials/employees of financial management are mutated frequently (factor loading 0.641).

8) Variable (Q27) A lateness in arranging in auction implementation schedule. (factor loading 0.419).

c. Third factor (eigenvalues 2.169) is called competence factors. Variables forming this competence factors can be described in details as follow:

1) Variable (Q1) There is a culture of postponing the work in working unit, indiscipline, etc. (factor loading 0.630).

2) Variable (Q10) Activity planning which is not aligned with the requirements. (factor loading $0.610)$.

3) Variable (Q12) Incompetent goods/services provider. (factor loading 0.694).

4) Variable (Q13) The implementation of activity/project is not subject to the plan/schedule set out in page 3 DIPA or Expenditure Budget Plan (Rencana Anggaran Belanja - "RAB") (factor loading 0.627).

5) Variable (Q19) Lack of understanding regarding regulations on payment mechanism. (factor loading 0.451).

6) Variable (Q22) Disharmony in the regulation regarding planning, implementation and disbursement of funds. (factor loading 0.633).

d. Fourth factor (eigenvalues 1.616) is called technical obstacles factors. Variables forming this technical obstacles factors can be described in details as follow:

1) Variable (Q8) The problems related to the consultant such as consultant who has not been assigned, the assigned consultant is resign, unavailability of consultant qualification and required experts (factor loading 0.722 ).

2) Variable (Q9) Lack of goods/service procurement procedure socialization according to applicable regulations (factor loading 0.833 ). 
3) Variable (Q15) Activity implementation that needs to wait for instruction from $\mathrm{K} / \mathrm{L}$ central office (factor loading 0.487 ).

4) Variable (Q26) Goods/services unit price in cost standard (SBU/SBK) is too low/high (factor loading 0.515).

e. Fifth factor (eigenvalues 1.317) is called administrative factors. Variables forming this administrative factor can be described in details as follow:

1) Variable (Q20) SPM errors due to ineligibility (factor loading 0.517 ).

2) Variable (Q21) Incompetent procurement human resources (factor loading 0.673 ).

f. Sixth factor (eigenvalues 1.119) is called document factors. Variables forming this document factors can be described in details as follow:

1) Variable (Q14) Delay in budget revision process. (factor loading 0.585).

2) Variable (Q24) Decree of Appointment/Replacement of KPA, PPK, PP-SPM Treasury Officials and Spending Treasurer is late to be specified (factor loading 0.831 ).

\subsection{Association to the Previous Studies}

As specified in the previous section, there were several studies conducted to find out the matters decelerating budget absorption and accumulation of absorption in the IV quarter. Among other things are Herriyanto (2012), collaboration research of BKF, LPEM-UI, and World Bank team (2012), Siswanto and Rahayu (2010), Miliasih (2012), Widjanarko (2013), and Fitriany (2015).

If referring to the year of research conducted, majority of these research, excluding studies conducted by Widjanarko (2013) as well as Fitriany (2015), are using the data of year 2011 and 2010 and the previous years. The result of those research can be used as reference. However, due to the fact that that research was conducted in the years when the condition of regulation and policy, work flow, or the facilities and infrastructures were different from the current condition, then there is a possibility that there were conditions which has not been portrayed by those research, particularly for the current condition.

For example, a regulation about DIPA revision in 2012 which was no longer applicable in 2014, the initial implementation of State Budget and Treasury System in all KPPN, and amendment on regulations regarding goods and services procurement such as President Regulations No. 54 Year 2010 which has been amended for several times, among other things, by President Regulations No. 35 Year 2011, President Regulations No. 70 Year 2012, President Regulations No. 172 Year 2014, and the last one is President Regulations No. 4 Year 2015. Such amendment matters may develop probability of incapability of previous studies to portray the real current condition, so that it is required for re-studying with improvement and update on the variables and research methodology. The research conducted by the author has shown an attempt to includes new research variables of which in it, there are amendments on the regulations and policy, work flow, or facility and infrastructure existing in current condition.

Other matter differentiating this research is selection of respondents. By considering that the research is only limited to capital and goods spending realization, in this research, the questionnaire is distributed only to the respondents who act as officials of financial management that manage capital and goods expenditure ceiling, and to other goods and services procurement officials. Moreover, by referring to the limitation of indicator variation that can be included by the previous studies, this research is expected to be a completing puzzle piece as a representative or all existing indicators/variables variation. 


\subsection{Factor Discussion}

In the framework of budgeting based on performance, budget absorption is not a target for budget allocation. However, by taking into account our current economic condition, the dominant variables that drives its growth is consumption factor, an expansive governmental expenditure is also become a determining factor of such growth. A failure in budget absorption target may disturb the attempt to improve economic growth.

In the attempt to improve budget absorption, budgeting plays an essential role, since if it is done properly, it shall ease the implementation of the budget. Improper planning of budget is often incurring obstacles in the implementation, so that it shall be revised and even it cannot be realized at all. According to the conducted factor analysis, it can be identified that the cause of slow absorption of budget in working units particularly in KPPN Jakarta 2 payment area, can be categorized into six factors of which details are as follow:

1. Coordination factors represent variance as many as $28.839 \%$.

2. Organizational culture factors represent variance as many as $10.617 \%$.

3. Competence factors represent variance as many as $8.035 \%$.

4. Technical obstacles factors represent variance as many as $5.985 \%$.

5. Administrative factors represent variance as many as $4.878 \%$.

6. Document factors represent variance as many as $4.145 \%$.

Therefore, all existing factors represent the total number of variance as many as $62.5 \%$. The remaining left of $37.5 \%$ is described by other factors out of those specified six factors above.

\subsection{Coordination factors}

According to the conducted factor analysis, there are six question items forming coordination factors, namely: (Q16) Activity budget is blocked/marked since there is no supporting data; (Q18) The centered-implementation materials/goods procurement which is received late; (Q28) A difficulty in performing coordination between central unit and the regional unit; (Q29) Budget Plan (Rencana Anggaran Biaya - "RAB") does not match to the cost unit; (Q30) Specification of goods.materials is unavailable/hard to obtain. According to the distribution of percentage of respondents' answers on the variables forming coordination factors, majority of the respondents responding agree and extremely agree is as many as $60.38 \%$ in average.

This first factor is called coordination factor since the selection of this word represents the overall characteristics of factors forming this first factor in general. In addition, from several variables that form this factor, the value of factor loading for particular variables is higher compared to the other which shows that this variable has stronger tendency compared to other variables in this factor. This is represented by variable (Q28) A difficulty in performing coordination between central unit and the regional unit (factor loading 0.781 ), and variable (Q29) Budget Plan (Rencana Anggaran Biaya - "RAB") does not match to the cost unit (factor loading 0.788 ) of which both of them represent lack of coordination.

Coordination is one of the management functions that holds similar important role and is equal to the other management functions. A success on coordination shall warrant a success of job implementation or achievement of organizational objectives. Coordination is a synchronized and orderly attempt to provide the exact amount and time and to direct the implementation in order to generate a similar and harmonious actions on the specified targets. In other words, coordination is an integration process of activities objectives in separated working units (departments or other functional sections) of an organization to achieve organizational objectives efficiently. 
Problems related to this coordination is generally can be anticipated by improving coordination by repairing communication between instances either vertically above, below or peer-to-peer. Therefore, in the future, this phenomenon of delay in budget absorption in central government can be reduced, and the advancing impact is for the implementation APBN to be more effective and may provide benefits to the development of this Country optimally.

\subsection{Organizational culture factors}

According to the conducted factor analysis, there are eight question items forming organizational culture factors, namely: (Q3) There is no reward \& punishment mechanism in working unit budget management; (Q4) The limitation of certified goods/services procurement officials; (Q5) A fear and circumspection in implementing goods/service procurement; (Q6) Reluctance to act as procurement officials due to imbalance between risk of job and the reward received; (Q7) Multitasking in Procurement Committee title; (Q23) A mistake in account determination, so that budget documents need to be revised; (Q25) Officials/employees of financial management are mutated frequently; (Q27) A lateness in arranging in auction implementation schedule. According to the distribution of percentage of respondents' answers on the variables forming organizational culture factors, majority of the respondents responding agree and extremely agree is as many as $59.01 \%$ in average.

Problems related to organizational culture as set out in the variables above can be resolved by repairing the system of HR management, among other things, is by sending the employees for training and education of goods and services procurement in order to obtain certificates, implementing employee mapping and filling the empty posts or the ones lack of the number of certified procurement officials, cooperating with Ministry of Finance in the form of assigning a certified employee of Ministry of Finance to implement procurement process, and by ordering the employees transferred to other unit to train and guide other employees that will replace their position as financial manager so that there will be knowledge transfer regarding financial management in such office.

The problems related to this organizational culture can be resolved by considering source of problems. If it is related to motivation, an approach that can be done is by providing incentive in the form of reward and material, or if needed, a law protection for the officials of financial management so that the fear and reluctance shown by these officials can be mitigated. If it is related to HR management, the solution is by reforming the bureaucracy mainly related to the matters similar to the improvement of employee transfer pattern, employee potential mapping and other things related to HR management. If the problem is related to human error and employee discipline, the solution offered is by improving internal control and an improvement on business process particularly for the things related to HR management.

\subsection{Competence factors.}

According to the conducted factor analysis, there are six question items forming competence factors, namely: (Q1) There is a culture of postponing the work in working unit, indiscipline, etc.; (Q10) Activity planning which is not aligned with the requirements; (Q12) Incompetent goods/services provider; (Q13)The implementation of activity/project is not subject to the plan/schedule set out in page 3 DIPA or Expenditure Budget Plan; (Q19) Lack of understanding regarding regulations on payment mechanism; (Q22) Disharmony in the regulation regarding planning, implementation and disbursement of funds. According to the distribution of percentage of respondents' answers on the variables forming competence factors, majority of the respondents responding agree and extremely agree is as many as $53.04 \%$ in average.

This third factor is called competence factor since the selection of this word represents the overall characteristics of factors forming this third factor in general. In addition, from several 
variables that form this factor, the value of factor loading for particular variables is higher compared to the other which shows that this variable has stronger tendency compared to other variables in this factor. This is represented by variable (Q12) Incompetent goods/services provider. (factor loading 0.694 ) representing the issues sourced from competence factor.

Several solutions that can be performed to resolve the problem of delay in budget absorption caused by factors related to the competence, depend on the type of its basic characteristics of competence. If it is related to personal, nature and motive concepts, the solution is by reward and punishment and enforcement on employee discipline. Meanwhile, if it is related to knowledge and skill, the solution is by continuous training and education for the employees until they reach their capability and competence required according to their fields.

\subsection{Technical obstacles factor}

According to the conducted factor analysis, there are four question items forming technical obstacles factors, namely: (Q8)The problems related to the consultant such as consultant who has not been assigned, the assigned consultant is resign, unavailability of consultant qualification and required experts; (Q9) Lack of goods/service procurement procedure socialization according to applicable regulations; (Q15) Activity implementation that needs to wait for instruction from K/L central office; (Q26) Goods/services unit price in cost standard (SBU/SBK) is too low/high. According to the distribution of percentage of respondents' answers on the variables forming technical obstacles factors, majority of the respondents responding agree and extremely agree is as many as $45.43 \%$ in average.

Upon these technical obstacles, they should be resolved by solution subject to the source and types of obstacles. An obstacle related to unavailable consultant and experts can be anticipated by penalty for the consultant or experts showing default, it can be resolved by searching for consultant or experts earlier. Communication improvement between central and regional office needs to be done so that if there are policies of programs of which nature requires an instruction from central office, the regional office know as per when the instruction for activities will be issued and will also be able to notify the central office regarding activity of this type. An issue related to the procurement whether it is unmatched unit price or lack of socialization, these issues can be resolved by guides and cooperation with the relevant instances, or by performing suggestions on change related to cost standard.

\subsection{Administrative factor.}

According to the conducted factor analysis, there are two question items forming administrative factors, namely: (Q20) SPM errors due to ineligibility; (Q21) Incompetent procurement human resources. According to the distribution of percentage of respondents' answers on the variables forming administrative factors, majority of the respondents responding agree and extremely agree is as many as $43.27 \%$ in average.

Budget management has specified administrative requirements as a form of internal control upon the managed financial resources. Related to these administrative factors, rejection variable on SPM due to ineligibility of (Q20) is the noncompliance to the administrative issue. In the event of incompetent procurement human resources. (Q21), the procurement organizers which is not fully understand administrative process in the procurement of goods and services will be considered as incompetent. Nonetheless, in the other hand, these procurements organized are competent in another field.

Therefore, a solution to anticipate the problem related to this administration can be conducted by various matters. Among other things are improving assistance and guidance by Directorate General of Treasury as BUN authority or Institution of Government Goods/Services Procurement Policy (Lembaga Kebijakan Pengadaan Barang/Jasa 
Pemerintah - "LKPP") in the form of socialization, technical guiding, or education and training as well as certification in working units in their area or to the officials of goods and services procurement.

\subsection{Document factors}

According to the conducted factor analysis, there are two question items forming document factors, namely: (Q14) Delay in budget revision process; and (Q24) Decree of Appointment/Replacement of KPA, PPK, PP-SPM Treasury Officials and Spending Treasurer is late to be specified. According to the distribution of percentage of respondents' answers on the variables forming document factors, majority of the respondents responding agree and extremely agree is as many as $45.67 \%$ in average.

There are times that the working unit at the area are waiting for budget revision document that is not promptly issued. As a result, all disbursement related to this revised budget is yet to be conducted if this DIPA ceiling of this working unit in a budget is ran off meanwhile the revision process is yet to complete. It is also frequently occurred, the problems occurring is the decree of appointment/replacement treasury officials is late to be specified. As a result, the working unit cannot perform disbursement of any budget as long as they are still waiting for the issuance of the decree.

A solution to be done in order to resolve this issue is by an improvement upon coordination and communication channel between regional offices and central office, whether to vertical instances above the working units or vertical instances above State Treasury Service Office (Kantor Pelayanan Perbendaharaan Negara - "KPPN"). Moreover, in order to accelerate revision process in the Ministry of Finance, the revision process should be able to be done using one stop service, so that there is an efficiency and it may accelerate the process of budget absorption for K/L.

\section{CONCLUSION AND RECOMENDATIONS}

According to the result of data analysis and discussion in previous chapters, several conclusions can be drawn, as follow:

1. According to the conducted factor analysis, there are six factors frequently decelerating budget spending absorption of central government particularly in working unit scope in KPPN Jakarta 2 payment area. Overall, the six factors found are able to describe indicator variance as many as $62.5 \%$. It means that, the 27 examined factor will be able to describe $62.5 \%$ of overall indicator variations. Meanwhile, as for the remaining, as many as $37.5 \%$, they will be described using other factors apart of those six factors.

2. The six factors formed are:

a. Coordination factors describes indicator variation as many as $28.839 \%$.

b. Organizational culture factors describes indicator variation as many as $10.617 \%$.

c. Competence factors describes indicator variation as many as $8.035 \%$. Technical obstacles factors describe indicator variation as many as $5.985 \%$.

d. Administrative factors describe indicator variation as many as $4.878 \%$.

e. Document factors describes indicator variation as many as $4.145 \%$.

In order to resolve the issue of slow absorption of budget in central government working units, below are several things suggested by the author:

1. The Ministry of Finance shall coordinate and remind Institutional Ministry to promptly deliver the suggestions of blocking opening, and promptly fulfilling the requirements of unfulfilled budget allocating. 
2. Improving coordination with central instance or other relevant instances. It may come out int the form of providing help desk to improve the communication of central and regional units, or a service such as online and bi-directional APBN care to collect consultations upon obstacles in the field or information provision regarding progress status of processing the documents related to APBN.

3. An reward and punishment mechanism equal and proportional to the risk of jobs taken related to budget absorption needs to be arranged. And it should also add a clear law protection for budget executors/organizers.

4. K/L sends several employees required to obtain certification of procurement officials, or to employ the employees assigned for the Ministry of Finance certified as procurement officials particularly to resolve the issue on goods and services procurement.

5. The employees that will be transferred to other units shall train and guide other employees replacing their position as financial manage so that there will be knowledge transfer regarding financial management in such office.

6. A training and education for the employees needs to be done until they reach their capability and competence required according to their fields.

7. K/L may search for consultant or experts earlier or implement penalty policy for the consultant or experts showing default.

8. Assistance and guides on working units by KPPN as BUN in the region.

\section{CONCLUSION AND RECOMMENDATIONS}

This paper observed three SIDS and conducted an empiric analysis of possible methods of transmission of the so-called natural resource curse. The preliminary findings are that there is evidence of both indirect methods of transmission through political instability, as well as direct transmission through harming economic growth in countries where economic growth is almost entirely dependent on one source of revenue. In Bahrain and Barbados, we find that there is a direct element of transition directly through natural capital towards economic growth.

There are two distinct and almost unrelated difficulties in conducting further research on the topic. One difficulty is the lacking consensus of which variable should be used to account for natural capital and the diverse results across the scientific community which have largely been impacted by the use of completely different variables. The second is overcoming difficulties resulting from the "smallness" of the economy, especially, as noted by Castello and Ozawa (1999), their insufficient diversification and danger to exogenous shock. While diversification may not provide immediate positive impacts, it is a necessary element in ensuring the sustainability of these small economies.

\section{ACKNOWLEDGEMENTS}

The author thanks all parties who assist in conducting this research. Without reducing the roles of unstated parties, special thanks are delivered to Directorate General of Treasury, particularly to KPPN Jakarta II and all respondents willingly to participate in this research. 


\section{REFERENCES}

- Abubakar. (2015, November 20). Persepsi Penumpang tentang Efektivitas Strategi Pencegahan Kejahatan TransJakarta dalam Mengatasi Terjadinya Pencopetan. Retrieved from Tesis Mahasiswa Fakultas Ilmu Sosial dan Ilmu Politik Universitas Indonesia:

- Amir, M. T. (2015). Merancang Kuesioner: Konsep dan Panduan untuk Penelitian Sikap, Kepribadian, dan Perilaku. Jakarta: Prenadamedia Group.

- BKF, LPEM-UI, \& IBRD. (2015, November 20). Identifikasi Hambatan dalam Pelaksanaan Anggaran di Sektor Infrastruktur, Studi Penelusuran DIPA. Retrieved from

- Fitriany, N., Masdjojo, Nasiansenus, G., \& Suwarti, T. (2015). Exploring The Factors That Impact The Accumulation of Budget Absorption In The Fiscal Year 2013: A Case Study in Pekalongan City of Central Java Indonesia. South East Asia Journal of Contemporary Business, Economics and Law, Vol. 7.

- Ghozali, I. (2013). Aplikasi Analisis Multivariate dengan Program IBM SPSS 21 Update PLS Regresi Edisi ke-7. Semarang: Badan Penerbit Universitas.

- Herriyanto, H. (2015 , November 20). Faktor-faktor yang Mempengaruhi Keterlambatan Penyerapan Anggaran Belanja pada Satuan Kerja Kementerian/Lembaga di Wilayah Jakarta. Retrieved from Tesis Mahasiswa Fakultas Ekonomi Universitas:

- Miliasih, R. (2015, November 18). Analisis Keterlambatan Penyerapan Anggaran Belanja Satuan Kerja Kementerian Negara/Lembaga TA 2010 di Wilayah Pembayaran KPPN Pekanbaru. Retrieved from TesisMahasiswa Fakultas Ekonomi Universitas Indonesia:

- Sarwono, J. (2014). Rumus-rumus Populer dalam SPSS 22 untuk Riset Skripsi. Jakarta: Penerbit Andi.

- Sekaran, U. (2003). Research Methods for Busniess. Southern Illinois: John Wiley\&Sons, Inc.

- Sigit Wijanarko. (2015, November 20). Analisis Faktor-Faktor Yang Mempengaruhi Penyerapan Anggaran di Kementerian Hukum dan HAM Tahun 2013. Retrieved from Thesis Mahasiswa Fakultas Ekonomi Universitas Indonesia:

- Susanto, A. D., \& Rahayu, S. L. (2015, November 20). Faktor-Faktor Penyebab Rendahnya Penyerapan Belanja Kementerian/Lembaga TA 2010. Retrieved from Fiskal Kemenkeu:

- Swaramarinda, D. R., \& Andriani, S. (2011). Pengaruh Pengeluaran Konsumsi dan Investasi Pemerintah Terhadap Pertumbuhan Ekonomi Indonesia. Econo Sains IX, 95-105.

- http://stats.oecd.org/glossary/detail.asp?ID=1730(Retrieved 11/12/2016). 